\title{
Diarrheagenic Escherichia coli pathotypes isolated from children with diarrhea in the Federal Capital Territory Abuja, Nigeria
}

\author{
Casmir Ifeanyichukwu Cajetan Ifeanyi ${ }^{1}$, Nkiruka Florence Ikeneche ${ }^{2}$, Bassey Enya Bassey ${ }^{3}$, Nazek Al- \\ Gallas $^{4}$, Ridha Ben Aissa ${ }^{4}$, Abdellatif Boudabous ${ }^{5}$ \\ ${ }^{1}$ Department of Veterinary Microbiology, Faculty of Veterinary Medicine, University of Abuja, Abuja, Nigeria \\ ${ }^{2}$ Department of Medical Microbiology, College of Health Science, University of Abuja, Abuja, Nigeria \\ ${ }^{3}$ World Health Organization Office, Abuja, Nigeria \\ ${ }^{4}$ Laboratoire de Controle des Eaux et Denrées Alimentaires, Institut Pasteur de Tunis, Tunisia \\ ${ }^{5}$ Laboratoire de Microbiologie, Faculté des Sciences deTunis, Tunis, Tunisia
}

\begin{abstract}
Introduction: Escherichia coli are frequently isolated from diarrheic children in the Federal Capital Territory Abuja, Nigeria, but their virulent properties are not routinely evaluated. Therefore, the etiology of childhood diarrheal disease attributable to diarrheagenic Escherichia coli (DEC) in Abuja, Nigeria remains unknown.

Methodology: Stool specimens from 400 acute diarrheic children between 0 and 60 months of age were studied.E. coli strains isolated were evaluated by polymerase chain reaction (PCR) for nine virulence genes and HEp-2 cell adherence to detect and identify five distinct diarrheagenic E. coli categories.

Results: Diarrheagenic E.coli was detected in 51 (12.8\%) of the diarrheic children. The observed DEC pathotypes were enteropathogenic E. coli (EPEC) in $18(4.5 \%)$ children, enterotoxigenic E. coli (ETEC) in $16(4.0 \%)$, enteroaggrative E. coli (EAEC) in 8 (2.0\%), enterohaemorrhagic E. coli (EHEC) in $6(1.5 \%)$, and enteroinvasive E. coli (EIEC) in $3(0.8 \%)$. Four (1.0\%) EPEC strains with only the eae+ gene that adhered diffusely to HEp-2 cell were identified as atypical EPEC. All the DEC categories except atypical EPEC were identified in children between 6 and 12 months of age.

Conclusions: This study underscores the need for routine evaluation of diarrheic children for virulence properties of infectious DEC. Atypical EPEC are emerging among the DEC pathotypes isolated from childhood acute gastroenteritis in Abuja, Nigeria.
\end{abstract}

Key words: diarrheagenic; virulence genes; pathotype.

J Infect Dev Ctries 2015; 9(2):165-174. doi:10.3855/jidc.5582

(Received 06 July 2014 - Accepted 08 October 2014)

Copyright $(2015$ Ifeanyi et al. This is an open-access article distributed under the Creative Commons Attribution License, which permits unrestricted use, distribution, and reproduction in any medium, provided the original work is properly cited.

\section{Introduction}

Diarrheal diseases are a major cause of morbidity and mortality in resource-limited countries [1], including Nigeria [2]. Of the 4.879 million global deaths of children under five years of age due to infectious diseases, diarrhea alone caused by bacterial, viral, and parasitic pathogens accounted for 0.801 million deaths in 2010 [3]. Escherichia coli is one of the members of the family Enterobacteriaceae, which resides as a commensal flora in the intestinal lumen of animals and humans but can cause diarrhea by different mechanisms [3]. This underscores the importance of diarrheagenic E. coli (DEC) as an enteric pathogens that causes a wide variety of gastrointestinal diseases, particularly in children [4]. Each type of E. coli diarrhea is associated with a different pathotype of E. coli, and each pathotype has characteristic virulence determinants that contribute to its pathogenic mechanisms [5]. Notably, DEC strains cannot be easily distinguished from the normal fecal flora using conventional phenotypic methods; while in-vitro assay can detect toxins, adherence or invasion phenotypes of DEC are cumbersome [6]. This task of identification and differentiation of DEC associated with diarrhea has been greatly simplified by the advent of polymerase chain reaction (PCR) technology [7]. Molecular identification and classification of DEC is based on the presence of different chromosomal and/or plasmid-encoded virulence genes that are absent in commensal E. coli [8]. There are at least five DEC pathotypes, based on their pathogenic mechanisms; these include enteropathogenic E. coli (EPEC), enterotoxigenic E. coli (ETEC), enteroaggregative $E$. coli (EAEC), enteroinvasive E. coli (EIEC), and 
enterohaemorrhagic E. coli (EHEC) (also known as Shiga toxin-producing $E$. coli or verocytotoxigenic $E$. coli) [9]. Diffusely adherent E. coli (DAEC), also known as diarrhea-associated hemolytic E. coli, and cytolethal distending toxin-producing $E$. coli (CDTEC) have also been described as diarrheagenic, but their role in human diseases, including diarrhea, has not yet been established $[9,10]$. EPEC strains that produce the attaching and effacing (A/E) lesions without stx genes and have the EPEC adherence factor (EAF) plasmid are classified as typical. Atypical EPEC strains lack the EAF plasmid, which has been shown to contain a 14-gene bundle-forming pilus operon that encodes a type IV pilus (bundle-forming pilus) [11]. Some atypical EPEC strains express the intimin-mediated localized adherence-like pattern [12]. ETEC has two major virulence associated factors, the heat-stable (ST) and/or heat-labile (LT) enterotoxins, and several antigenic fimbriae known as colonization factors (CFs) [13]. EAEC are defined as strains that do not secrete elt or sta gene products and that adhere to HEp-2 cells in an aggregativeadherence (AA) pattern [8]. EHEC, also known as Shiga toxinproducing E. coli or verocytotoxigenic E. coli[9], produces Shiga toxins (Stx1, Stx2, and their variants) as its major virulence characteristic, and the genes responsible for that are mostly bacteriophage borne $[14,15]$. EIEC elaborates the invasion plasmid antigen (ipaH), which is similar to Shigella species by means of genetic traits of virulence [16,17]. Numerous studies have reported that the epidemiologic features and prevalence of DEC pathogens as causative agents of diarrhea are known to vary from one region of the world to another and even between and within countries in the same geographical area [9,18-22]. Diarrheal episodes in many developing countries affecting children younger than five years of age have been attributed to DEC such as ETEC, EPEC, and EAEC, which are considered to be the most important enteric pathogens responsible for $30 \%$ to $40 \%$ of all diarrheal episodes $[23,24]$. In southwestern Nigeria, EHEC and EAEC were significantly associated with diarrhea [25]. However, in another study carried out in southeastern Nigeria, EPEC was reported to be the most prevalent DEC, while EAEC, ETEC, and EIEC were all significantly associated with diarrhea [26]. Limited information is available about the current status of the detection of the virulence genes of DEC by PCR in Abuja, Nigeria. This is because molecular techniques are not applied routinely to detect DEC in medical laboratories in Abuja, Nigeria. In this study, we aimed to investigate the relative prevalence of selected virulence factors of EPEC, ETEC, EAEC, EHEC, and EIEC isolated from stool samples of acute diarrheic children.

\section{Methodology}

Study population

The pediatric patients included in the study came from two tertiary hospitals (University of Abuja Teaching Hospital [UATH] and National Hospital [NHA]), two secondary hospitals (Maitama and Nyanya districts hospitals [MDH and $\mathrm{NDH}]$ ), and one primary health center (Mpape Health Center [MHC]), all located in Abuja, Nigeria. Abuja has a total population of $1,405,201$, with 740,489 males and 664,712 females, including 281,040 children five years of age and younger. The inhabitants of Abuja are top politicians, civil servants, traders, and natives, who are mostly farmers. Clinical features and risk factors recorded from diarrheic children included nausea, vomiting, abdominal pain, body temperature $\geq 38.0^{\circ} \mathrm{C}$, feeding type, diarrhea type, duration of diarrhea, drug use, and hospitalization type (Table 1).The study protocol was reviewed and approved by the ethics committees of National Hospital Abuja and University of Abuja Teaching Hospital Gwagwalada, Abuja.

Specimen collection, isolation, and identification of E. coli

Between July and December 2011, 400 stool samples of children five years of age who and younger met the inclusion criteria of diarrhea characterized by the occurrence of three or more loose or watery stool or at least one bloody loose stool in a 24-hour period were enrolled in the study. Stool specimens from diarrheic children were collected in clean, sterile, wide-mouth, dry, leak-proof containers, stored at $4{ }^{\circ} \mathrm{C}$ at the hospital of collection, and transported in cold boxes to microbiology laboratory for analysis. The stool specimens were inoculated onto MacConkey agar (Oxoid, Basingstoke, United Kingdom) and sorbitol MacConkey agar (Oxoid) containing cefixime $(0.05 \mathrm{mg} / \mathrm{L})$ and tellurite $(2.5 \mathrm{mg} / \mathrm{L})$ and incubated for 24 hours at $37^{\circ} \mathrm{C}$ to isolate E. coli. Stool specimens were pre-enriched by inoculating stool specimens into brain-heart infusion (BHI) broth at a ratio of 1:10. 
Table 1. Clinical features and risk factors in diarrheic children infected with diarrheagenic E. coli pathotypes

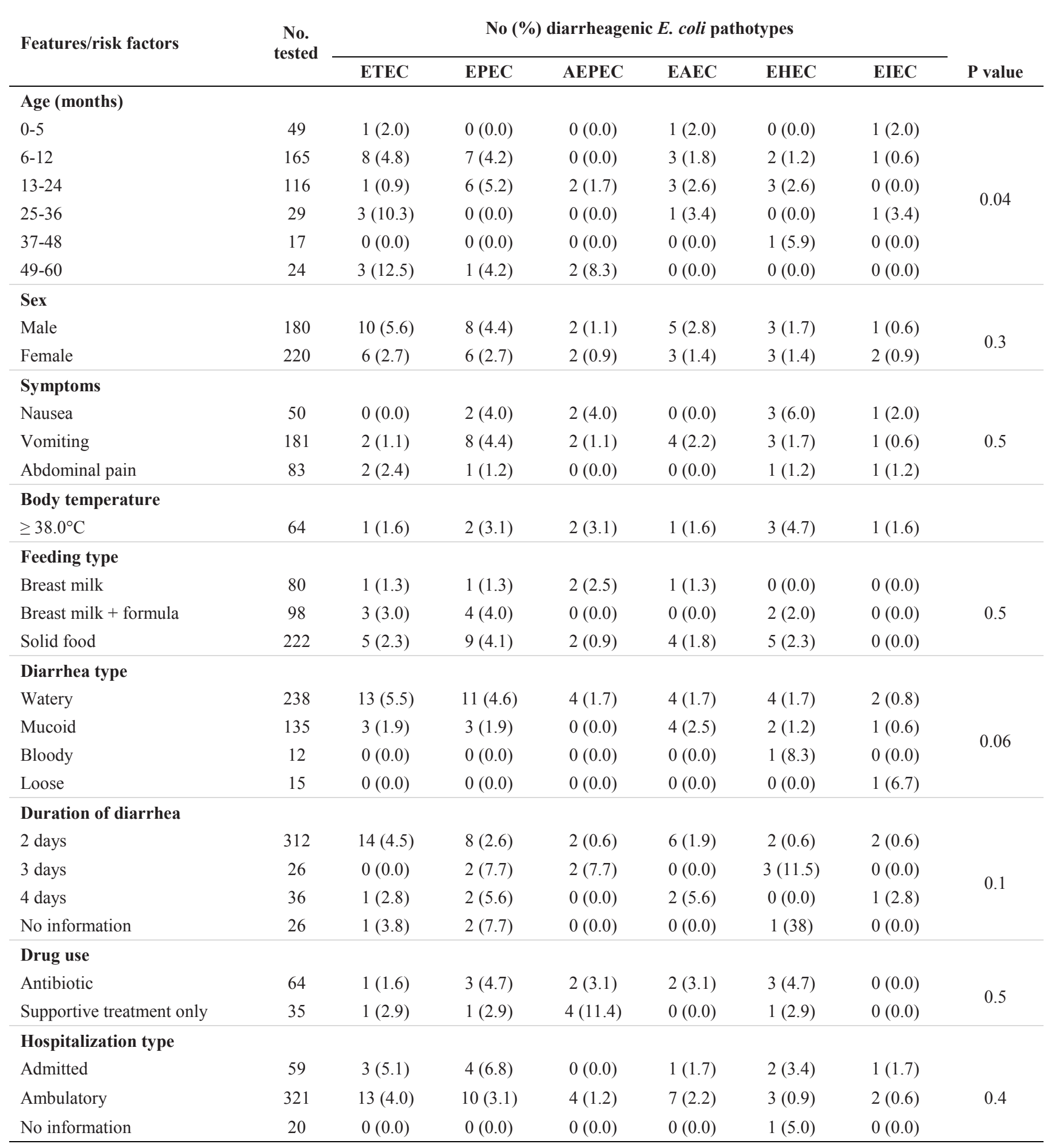


The pre-enrichment $\mathrm{BHI}$ broth was incubated at $35^{\circ} \mathrm{C}$ for three hours and afterward transferred into tryptone phosphate (TP) broth, incubated for enrichment at $44^{\circ} \mathrm{C}$ for 20 hours, and an aliquot of enriched broth was plated by streaking-out technique onto MacConkey and eosin-methylene blue (EMB) agar plates. Furthermore, the stool specimens were screened for the presence of blood and/or mucus and for ova/cysts of parasites using conventional microscopy and staining methods [27]. The agar plates were incubated at $37^{\circ} \mathrm{C}$ for 24 hours. Six suspicious $E$. coli colonies from each sample were studied by biochemical tests specific for $E$. coli strains, and identification was confirmed with the analytical profile index (API) 20E system (bioMérieux, Marcyl'Etoile, France). These E. coli strains were sent to Laboratoire de Contrôle des Eaux et Denrées Alimentaires, Institut Pasteur de Tunis, Tunis, Tunisia, where further characterization by virulence gene-targeted PCR assays and HEp-2 cell adherence (tissue culture assays) were performed to categorize specific pathotypes.

\section{DNA extraction}

All isolated E. coli strains (109 strains) were grown on Luria-Bertani (LB) broth (Sigma, St. Louis, USA) at $37^{\circ} \mathrm{C}$ for 24 hours. Genomic DNA was extracted according to the method described by AlGallas et al. [28]. Briefly, the DNA to be amplified was released from whole organisms by boiling. Bacteria were first harvested from $1.5 \mathrm{~mL}$ of an overnight LB broth culture (Sigma), suspended in 200 $\mu \mathrm{L}$ of sterile water, and boiled at $100^{\circ} \mathrm{C}$ for 15 minutes. Following centrifugation of the lysate, a 150$\mu \mathrm{L}$ sample of the supernatant was stored at $-20^{\circ} \mathrm{C}$ (in aliquot) as a template DNA stock and used as the target for PCR assays.

PCR detection of diarrheagenic E. coli

PCR was performed individually using nine virulence gene targeted assays for distinct DEC pathotypes. Each PCR assay was conducted in a final amplification reaction of $50 \mu \mathrm{L}$ containing $10 \mathrm{mM}$ Tris- $\mathrm{HCl}, \mathrm{pH} 8,50 \mathrm{mM} \mathrm{KCl}, 2 \mathrm{mM} \mathrm{MgCl} 2,0.25 \mathrm{mM}$ of each deoxynucleoside triphosphate (Amersham, Piscataway, USA), 2.5 units of Taq polymerase

Table 2. PCR primers used in this study to identify virulence markers

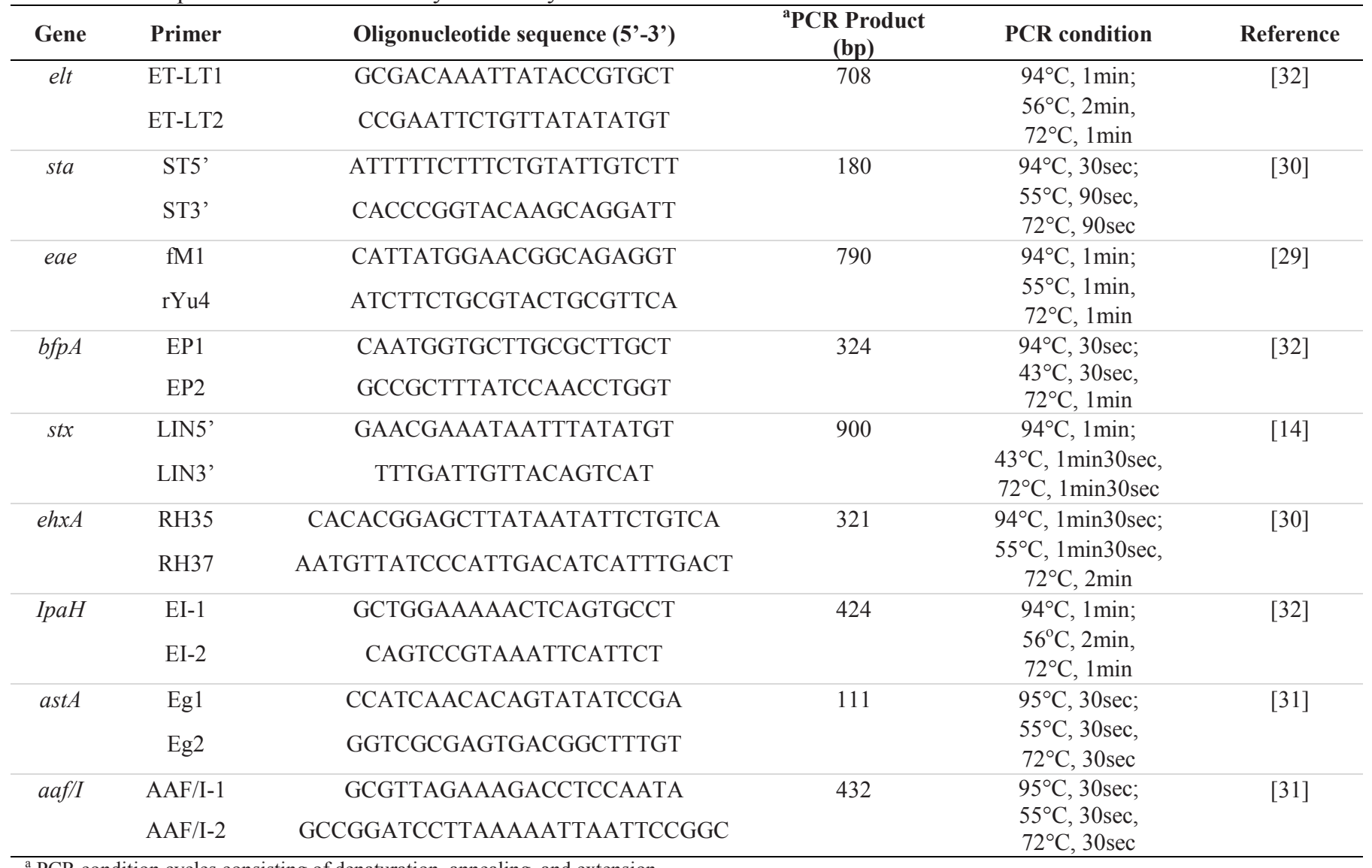

${ }^{\text {a }}$ PCR condition cycles consisting of denaturation, annealing, and extension 
(Amersham), and $25 \mathrm{pmol}$ of each primer. The reaction mixture was subjected to cycles of denaturation, annealing, and extension at PCR conditions described in Table 2. The amplified DNA products were resolved by electrophoresis on agarose gels and visualized by ultraviolet transillumination after staining with ethidium bromide. The PCRs were performed in an automated thermocycler (PerkinElmer, Waltham, USA). The primer pair used for the categorization of DEC were: for EPEC, attaching and effacing gene (eae $790 \mathrm{bp}$ ) and bundle-forming pilus

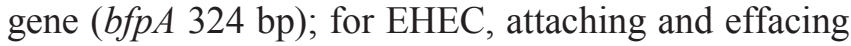
gene (eae 790 bp) [29], Shiga toxin gene (stx 900 bp), and enterohemolysin gene (ehxA 321 bp) [30]. To detect and identify the stx genes, the Lin-all system PCR followed by digestion with HincII to further identify stx 1 and stx 2 was performed [14]. The EAEC were identified by the amplification of heat-stable enterotoxin I gene (astA $111 \mathrm{bp}$ ) and aggregative adherence fimbria I (aaf/I) gene aafA-D (432 bp) [31]. PCR reactions for ETEC targeted the amplification of the heat-stable enterotoxin gene (sta 180 bp) geneand/or heat-labile enterotoxin gene (elt 708 bp), while the invasion plasmid antigen (ipaH $424 \mathrm{bp}$ ) was identified for EIEC [32]. DNA samples that possessed the relevant virulence gene(s) were obtained from the E. coli reference strain EPEC 2348/69 (O127:H6) for the eae and $b f p A$ genes (attaching and effacing gene and bundle-forming pilus gene), EAEC 17-2 for the ast $A$ and aaf/Igenes (heat-stable enterotoxin I and aggregative adherence fimbria I), EIEC 11741 for the $i p a H$ gene (invasion plasmid antigen), and ETEC H10407 for the elt gene (heat-labile enterotoxin). ETEC Jep5683 for the sta gene (heat-stable enterotoxin), EHEC EDL933 (O157:H7) for the stx and ehxA genes (Shiga toxin gene and enterohemolysin gene, respectively) were used as positive control in each PCR reaction. The nonpathogenic E. coli strain HB 101 was used as a negative control.

\section{HEp-2 cell adherence assay}

Bacterial isolates identified as DEC by PCR(virulence gene positive) were evaluated for the abilityto induce various adherence patterns on HEp-2 cells by standard methods [33].Accordingly, HEp-2 cells were grown overnight at $37^{\circ} \mathrm{C}$ to give a $50 \%$ confluence in Dulbecco's modified Eagle medium (Gibco BRL, Gaithersburg, USA) containing penicillin, streptomycin, and $10 \%$ fetal bovine serum on eight-well chamber slides (Labtek, Scotts Valley, USA). The Dulbeco medium used to grow the HEp-2 cells was replaced with Dulbeco's modified Eagle medium containing 1\% mannose. Bacteria colony of PCR-positive DEC were grown for 16 hours in Luria broth without shaking. The growth was washed with phosphate buffered saline (PBS). A $10-\mu \mathrm{L}$ volume of it was added to each of the wells of the eight-well chamber slides and incubated at $37^{\circ} \mathrm{C}$ in $5 \%$ carbon dioxide for three hours. The slides were washed again with PBS and fixed with 70\% methanol and stained with giemsa. E. coli strains that adhered to the HEp-2 monolayers were recorded as adhering in a localized, diffuse, or aggregative pattern.

\section{Vero cell assay}

Bacterial isolates PCR-positive for the stx gene were evaluated for cytotoxicity production on Vero cells by the method described by Al-Gallas et al. [28]. Briefly, the bacterial strains were inoculated into 10 $\mathrm{mL}$ of nutrient broth and incubated at $37^{\circ} \mathrm{C}$ overnight for 24 hours. After centrifugation at 7,000 xg for 10 minutes, supernatant filtrates were obtained with a $0.45 \mu \mathrm{m}$ pore-size filter (Polylabo, Strasbourg, France) and screened for verocytotoxicity. Serial dilutions of bacterial filtrates were done in a 96-well flat-bottom microtiter plate (Polylabo CA710) $\left(100 \mu \mathrm{L}\right.$ well ${ }^{-1}, 12$ wells strain 1 , dilution from $1 / 2$ to $1 / 256$ ). A total of $100 \mu \mathrm{L}$ of DMEM containing $10^{5}$ Vero cells in suspension was added to each well. The plate was incubated at $37^{\circ} \mathrm{C}$ in a $5 \% \mathrm{CO}_{2}$ incubator for 48 hours and was examined directly under an inverted microscope to estimate the degree of destruction of the Vero cell monolayer. E. coli EDL933 and E. coli HB101 were used as positive and negative controls, respectively.

\section{Data analysis}

Age and sex distribution of DEC infections were compared using SPSS version 16 command syntax reference. The Chi-square test was utilized to assess significant differences of variables at a $p$ value $<0.05$.

\section{Results}

A total of 400 children with diarrhea were included in the study. Forty-nine $(12.3 \%)$ of the diarrheic children were $0-5$ months of age. Of the total subjects, $165(41.3 \%)$ children were 6-12 months of age, $116(29.0 \%)$ were 13-24 months of age, 29 (7.3\%) were $25-36$ months of age, $17(4.3 \%)$ were $37-$ 48 months of age, and $24(6.0 \%)$ were $49-60$ months of age. The overall sex distribution was $180(45.0 \%)$ male and $220(55.0 \%)$ female. The occurrence of the clinical features/risk factors (Table 1), irrespective of 
the isolated DEC category, was not significant ( $\mathrm{p}>$ $0.05)$. From the 400 samples, at least one E. coli strain was identified in $109(27.3 \%)$ of the samples, and DEC was detected in $51(12.8 \%)$ of the diarrheic children studied. The age distributions of diarrheagenic E. coli among the diarrheal children were observed varyingly in the six age groups. ETEC, EAEC, and EIEC were the only pathotypes detected in the $0-5$ and 25-36 months age groups. Five diarrheagenic E. coli categories (EPEC, ETEC, EAEC, EHEC, and EIEC) were identified only in the 6-12 months age group. ETEC, EPEC, EAEC, and EHEC were isolated from the 13-24 months age group. Whereas ETEC and EPEC were detected in subjects 49-60 months of age, only one DEC pathotype (EHEC) was isolated in patients 37-48 months of age. The age distributions of diarrheagenic E. coli infection was significant $(\mathrm{p}<0.05)$, while the occurrence of DEC according to sex of subjects was not statistically significant $(\mathrm{p}>0.05)$.

Relative to patients' clinical symptoms, the following diarrheagenic Escherichia coli pathotypes were isolated most frequently: body temperature $\geq$ $38.0^{\circ} \mathrm{C}$ in three $(4.7 \%)$ EHEC cases; nausea in three $(6.0 \%)$ EHEC cases; vomiting in four $(2.2 \%)$ EAEC cases; and abdominal pain in two $(2.40 \%)$ ETEC cases. EPEC infection was highest in children fed with solid food $(9 ; 4.1 \%)$ followed by those on a combination of breast milk and formula milk (4; $4.0 \%)$. Fourteen $(4.5 \%)$ of ETEC was identified in patients with diarrhea duration not exceeding two days. Watery stool was the most common stool consistency in subjects, and 13 (5.5\%) of ETEC were isolated from subject presenting with watery diarrhea. However, there was no statistically significant difference between the occurrence of diarrhea type and isolation of diarrheagenic E. coli pathotype from all the diarrhea types. Antibiotic administration and supportive treatment of subjects was commonly associated with the isolation of all the pathotypes except EIEC. Interestingly, subjects infected with atypical EPEC $(4 ; 11.4 \%)$ had an increased need for supportive treatment.

The incidence of each virulence gene, and hence diarrheagenic categories, among the E. coli strains are shown in Table 3 . The most prevalent category was EPEC followed by ETEC, EAEC, EHEC, and EIEC. PCR showed that of the 400 diarrheic children, 18 (4.5\%) had EPEC infection, $16(4.0 \%)$ had ETEC infection, $8(2.0 \%)$ had EAEC infection, $6(1.5 \%)$ had EHEC infection, and $3(0.8 \%)$ had EIEC infection. The aaf $A-D$ gene was detected among the EAEC strains. The astA (enteroaggregative E. coli heat-stable enterotoxin 1 EAST1)genes were detected in 14 strains $(27.5 \%)$ of the 51 DEC strains detected in the diarrheic children. Out of these 14 strains that had the ast $A$

Table 3. Distribution of diarrheagenic Escherichia coli strains associated with diarrhea in children between zero and five years of age in Abuja, Nigeria

\begin{tabular}{|c|c|c|c|}
\hline Diarrheagenic $E$. coli & Virulence gene & Number of strains & Percentage \\
\hline EPEC total & & 18 & 4.5 \\
\hline (typical EPEC) & eae/bpfA & 14 & 3.5 \\
\hline (atypical EPEC) & eae & 4 & 1.0 \\
\hline \multirow{3}{*}{ ETEC total } & st & 2 & 0.5 \\
\hline & st/astA & 4 & 1.0 \\
\hline & elt & 6 & 1.5 \\
\hline (ETEC/EPEC) & $s t / b f p A / a s t A$ & 2 & 0.5 \\
\hline \multirow[t]{3}{*}{ EAEC total } & & 8 & 2.0 \\
\hline & ast $A$ & 7 & 1.8 \\
\hline & aaf $/ I$ & 1 & 0.3 \\
\hline \multirow[t]{2}{*}{ EHEC total } & & 6 & 1.5 \\
\hline & stx & 3 & 0.8 \\
\hline \multirow[t]{3}{*}{ EIEC total } & & 3 & 0.8 \\
\hline & ipaH & 2 & 0.5 \\
\hline & ipaH astA & 1 & 0.3 \\
\hline DEC TOTAL & & 51 & 12.8 \\
\hline
\end{tabular}

Data shown above is the prevalence of each virulence gene, and hence diarrheagenic $E$. coli categories, among the 400 diarrheic subjects. 
gene,7 were EAEC, 4 were ETEC, 2 were ETEC/EPEC, and 1 strain was EIEC. Uniquely, strains carrying both sta and ast $A$ genes (or in association with other genes) were found in $2(0.5 \%)$ subjects each for either combination. Only one combination of stx, eae, and $e h x A$ was detected, as shown in Table 3.

Results from the different study centers were analyzed as representing the prevalence of diarrheagenic $E$. coli from these localities. The prevalence of diarrheagenic $E$. coli in municipal hospitals were $10(12.8 \%)$ in NHA and $11(13.6 \%)$ in $\mathrm{MDH}$; in peri-urban hospitals, 14 (16.9\%) in UATH and $6(7.9 \%)$ in $\mathrm{NGH}$; and in a rural health center, MHC, $10(12.2 \%)$ were found. All DEC pathotypes were detected only in a rural (MHC) health center (Table 4). The peak prevalence of diarrheagenic E. coli occurred in the peri-urban hospital UATH 14 $(16.9 \%)$. Comparatively across the centers, the data showed that the prevalence of ETEC was significant for patients from municipal (NHA) $(\mathrm{p}<0.05)$, whereas EPEC was significantly $(\mathrm{p}<0.05)$ prevalent in the peri-urban (NGH) area.

\section{Discussion}

Patients with diarrhea associated with DEC in this study showed varying clinical features and risk factors. Watery diarrhea and vomiting are considered to be important clinical symptoms associated with sole infections caused by many forms of DEC [6]. The symptoms were substantially observed in the current study but not related to DEC category isolated. In Lagos, Nigeria, an earlier hospital-based study reported an established relationship between fever, vomiting, and hospitalization of diarrheic children [34]. Nonetheless, our data support the suggestion that infections with any of the diarrheagenic E.coli pathotypes are indistinguishable on the basis of clinical findings [35].

We identified all five classes of DEC in children with diarrhea in this study. The most dominant pathotype isolated was EPEC, followed by ETEC. These results concur with previous studies in West Africa that reported higher recovery rates for EPEC and ETEC and that have found them to be significantly associated with childhood diarrhea [36]. This study identified four atypical EPEC strains in acute diarrhea children. ETEC was the dominant pathotype detected in children 6-12 months of age while EPEC was dominant in children 13-24 months of age in this study. The prevalence of EPEC in the 13-24 months age group conforms to the report that EPEC infection is primarily a disease of infants younger than two years of age [35]. The detection of atypical EPEC in Abuja, Nigeria, is in consonance with recent findings in developing and developed countries of increased isolation of atypical EPEC [37]. Remarkably, these findings differ from previous reports by Nataro et al. [8] and Ratchtrachenchia et al. [38], which suggested that the prevalence of atypical EPEC is limited to industrialized countries and certain developing countries such as Brazil and Mexico. Even though the etiologic role of this sub-pathotype of EPEC in diarrhea has not been definitively established $[34,19,18]$, this finding underscores the emergence of atypical EPEC worldwide [18,8]. We identified ETEC in all age groups except in the 37-48 months group, from which no ETEC strain was isolated. The highest ETEC prevalence in our results was observed among children 49-60 months of age, which is similar to the findings of Riveria et al. and conforms with the commonly reported more frequently isolation of ETEC from children $>12$ months of age than from children $<$ 12 months of age [39]. This corroborates the fact that ETEC strains might be considerably important

Table 4. Distribution of diarrheagenic E. coli according to various hospital/health center locations in Abuja, Nigeria

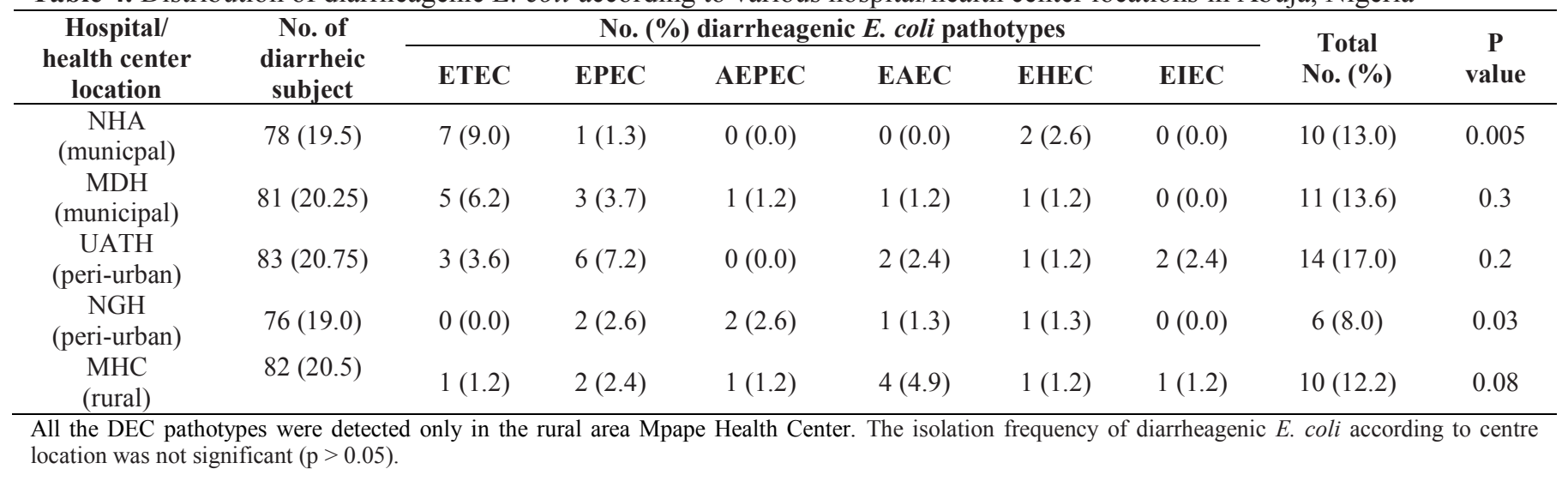


enteropathogens, especially in pediatric patients in the $0-5$ years age group [40].

In this study, the detection rate for EAEC was $2.0 \%$ and its occurrence was limited to children under 36 months of age. This observed rate is in sharp contrast with reported low and high detection rates of $5 \%-6 \%$ and $20 \%-38 \%$ in many studies from developing countries $[4,41,42]$. Furthermore, the result of the present study disagrees with the significant association of EAEC infection with children 0-2 months of age but not with older infants as reported from Venezuela [43]. Data regarding the prevalence of EAEC in southwestern Nigeria shows that EAEC was significantly associated with diarrhea [25]. In general, studies conducted in many countries have demonstrated the importance of EAEC in pediatric diarrhea $[44,45]$. It is therefore increasingly recognized as a cause of diarrhea worldwide, especially in developing countries [38,46]. This is probably due to the challenges of poor hygienic practices and very low standards of living in developing countries, and it implies that improvements in sanitary conditions and water quality can be effective control measures.

The result from this study revealed that EHEC strains were predominantly recovered from children 37-48 months of age. Notably, these EHEC strains were mainly from subjects who had non-bloody stools. This occurrence further stresses the fact that nonbloody diarrhea does not rule out EHEC infection [18]. Comparatively, Vilchez et al. [35] identified a few EHEC strains from children with diarrhea. Therefore, our finding is in concurrence with the low prevalence of EHEC infection in developing countries $[47,35]$. Evidently, the carrier rates of these pathogens have been judged to be as low as $<1 \%$ [9].

This study categorized three ipaH-specific PCRpositive strains as EIEC. The EIEC strains were found only in children $0-5,6-12$, and $25-36$ months of age enrolled from a hospital in a peri-urban are and a health center in a rural area. This data is in conformity with the results of other investigators, who reported that EIEC was associated with acute diarrhea in children of similar ages [18]. The role of EIEC in acute diarrhea of children in Nigeria has been largely equivocal. EIEC strains were not reported to be etiologic agents of childhood diarrhea in an earlier study in Lagos, Nigeria [48]. The report of EIEC from this study is comparable to that of Okeke et al. [36], and indicates the potential of EIEC as a pathogen responsible for diarrhea in Nigerian children. We observed variations and concomitance in the incidence of virulence genes of DEC strains. Only two DEC strains carried both sta and astA genes or in association with other virulence genes, while one combination of stx, eae, and $e h x A$ was detected. This occurrence is in agreement with reported concomitance virulence genes of DEC strains from a similar study in Tunis [18]. The results from this study highlighted the variations in prevalence and seasons by the DEC categories within Abuja, Nigeria. Diarrheagenic E. coli was the major enteropathogenic bacteria in diarrhea of children younger than five years of age and predominantly more prevalent in UATH $(17.0 \%)$, located in a peri-urban area. Since the virulence genes of DEC strains are not routinely evaluated in hospital-based laboratories in Abuja, Nigeria, our data is therefore of immense public health importance.

\section{Conclusions}

This study suggests that DEC is an important diarrhegenic agent and should be considered in routine studies and surveillance for childhood acute diarrheal disease. EPEC was predominantly recovered; it therefore underscores the need for routine evaluation of diarrheic children for virulence properties of infectious DEC. This study is the first report of atypical EPEC in this region of Nigeria and supports the recent ubiquitous emergence of this pathogenic strain. Further studies are needed to delineate the epidemiologic characteristics of DEC pathotypes in Abuja, Nigeria.

\section{Acknowledgements}

The authors are grateful to the children and their parents for kindly providing the stool samples. We thank the laboratory staff of all the hospitals and center for their contribution in collecting the samples for study and the staff of the Department of Biological Science, University of Abuja, for the logistic support. We also thank Laboratoire de Contrôle des Eaux et Denrées Alimentaires de l'Institut Pasteur de Tunis in Tunis, Tunisia for their valuable input into this study.

\section{Authors' contributions}

ICIC was the principal investigator, performed data entry and analysis, laboratory work and manuscript drafting; NFI participated in the planning and execution of the study; BEB reviewed draft manuscript and provide advice; NA participated in the planning and execution of the study, provide advice; RA and AB participated in the planning and execution of the study. 


\section{References}

1. Bryce J, Boschi-Pinto C, Shibuya K, Black RE; WHO Child Health Epidemiology Reference Group (2005) WHO estimates of the causes of death in children. Lancet 365 : 11471152.

2. Kosek M, Bern C, Guerrant RL (2003) The magnitude of the global burden of diarrhoeal disease from studies published 1992-2000. Bull World Health Organ 81: 197-204.

3. Liu L, Johnson HL, Cousens S, Perin J, Scott S (2012) Global, regional, and national causes of child mortality: an updated systematic analysis for 2010 with time trends since 2000. Lancet 379: 2151-2161.

4. Ali M, Mohamed Z, Klena J, Ahmed S, Moussa T, Ghenghesh K (2012) Molecular Characterization of Diarrheagenic Escherichia coli from Libya. Am J Trop Med Hyg 86: 866-871.

5. Donnenberg MS (2010) Enterobacteriaceae. In: Mandell GL, Bennet JE, Dolin R, editors. Principles and practice of infectious diseases, 7 th edition. Philadelphia: Elsevier Churchill Livingstone. 2815-2834.

6. Shetty V, Kumar S, Shetty A, Karunasagar I (2012) Prevalence and characterization of diarrheagenic Escherichia coli isolated from adults and children in Mangalore. India $\mathrm{J}$ Lab Physcians 4: 24-29.

7. Bischoff C, Luthy J, Altwegg M, Baggi F (2005) Rapid detection of DEC by real-time PCR. J Microbiol Methods 61: 335-341.

8. Nataro J, Kaper J (1998) Diarrheagenic Escherichia coli. Clin Microbiol Rev 11: 142-201.

9. Kaper J, Nataro J, Mobley L (2004) Pathogenic Escherichia coli. Nat Rev Microbiol 2: 123-140.

10. Shima A, Hinenoya A, Asakura M, Sugimoto N, Tsukamoto T, Ito H, Nagita A, Faruque S, Yamasak S (2012) Molecular Characterizations of Cytolethal Distending Toxin Produced by Providencia alcalifaciens Strains Isolated from Patients with Diarrhea. Infect Immun 80: 1323-1332.

11. Stone K, Zhang H, Carlson I, Donnenberg M (1996) A cluster of fourteen genes from enteropathogenic Escherichia coli is sufficient for the biogenesis of a type IV pilus. Mol Microbiol 20: 325-337.

12. Pelayo J, Scaletsky I, Pedroso M, Sperandio V, Giron J, Frankel G, Trabulsi L (1999) Virulence properties of atypical EPEC strains. J Med Microbiol 48: 41-49.

13. Isidean S, Riddle M, Savarino S, Porter C (2010) A systematic review of ETEC epidemiology focusing on colonization factor and toxin expression. Vaccine 29: 61676178.

14. Bastian S, Carle I, Grimont F (1998) Comparison of 14 PCR systems for the detection and subtyping of stx genes in shigatoxin-producing Escherichia coli. Res Microbiol 149: 457-472.

15. Garcia-Aljaro C, Muniesa M, Jofre J (2004) Prevalence of the stx2 gene in coliform populations from aquatic environments. Appl Env Micribiol 70: 3535-3540.

16. Sethabutr O, Vankatesan M, Murphy G, Eampokalap B, Hoge C, Echeverria P (1993) Detection of Shigellae and enteroinvasive Esherichia coli by amplification of the invasion plasmid antigen $\mathrm{H}$ DNA sequence in patient with dysentery. J Infect Dis 167: 458-461.

17. Alikhani M, Hashemi S, Aslani M, Farajnia S (2013) Prevalence and antibiotic resistance patterns of diarrheagenic Escherichia coli isolated from adolescents and adults in Hamedan, Western Iran. Iran J Microbiol 5: 42-47.
18. Al-Gallas N, Bahri O, Bouratbeen A, Ben Haasen A, Ben Aissa R (2007) Etiology of acute diarrhea in children and adults in Tunis, Tunisia, with emphasis on diarrheagenic Escherichia coli: prevalence, phenotyping, and molecular epidemiology. Am J Trop Med Hyg 77: 571-582.

19. Nataro J, Mai V, Johnson J, Blackwelder W, Heimer R, Tirrel S, Edberg S, Braden C, Glenn Morrs J, Hirshon J (2006) Diarrheagenic Escherichia coli infection in Baltimore, Maryland, and New Haven, Connecticut. Clin Infect Dis 43: 402-407.

20. Nguyen T, LeVan P, Le Huy C, Gia K, Weintraub A (2005) Detection and characterization of diarrheagenic Escherichia coli from young children in Hanoi, Vietnam. J Clin Microbiol 43: 755-760.

21. Paniagua $M$, Espinoza $F$, Ringman $M$, Reizenstein E, Svennerholm A, Hallander H (1997) Analysis of incidence of infection with enterotoxigenic Escherichia coli in a prospective cohort study of infant diarrhea in Nicaragua. J Clin Microbiol 35: 1404-1410.

22. Vernacchio L, Vezina R, Mitchell A, Lesko S, Plaut A, Acheson D (2006) Diarrhea in American infants and young children in the community setting: incidence, clinical presentation and microbiology. Pediatr Infect J 25: 2-7.

23. O'Ryan M, Prado V, Pickering L (2005) A millennium update on pediatric diarrheal illness in the developing world. Semin Pediatr Infect Dis 16: 125-136.

24. Clarke S (2001) Diarrheagenic Escherichia coli-an emerging problem? Diagn Microbiol Infect Dis 41: 93-98.

25. Okeke I, Ojo O, Lamikanra A, Kaper J (2003) Etiology of acute diarrhea in adults in southwestern, Nigeria. J Clin Microbiol 41: 4525-4530.

26. Nweze E (2010) Aetiology of diarrhea and virulence properties of diarrheagenic Escherichia coli among patients and healthy subjects in southeast Nigeria. J Health Popul Nutr 28: 245-252.

27. Leiva B, Lebbad M, Winiecka-Krusnell J, Altamirano I, Tellez A, Linder E (2005) Overdiagnosis of Entamoeba histolytica and Entamoeba dispar in Nicaragua: a microscopic, triage parasite panel and PCR study. Arch Med Res 37: 529-534.

28. Al-Gallas N, Ben Aissa R, Annabi T, Bahri O, Boudabous A (2002) Isolation and characterization of shiga toxin producing Escherichia coli from meat and dairy products. Food Microbiol 19: 389-398.

29. Beadudry M, Zhu C, Fairbrother J (1996) Genotypic and phenotypic characterization of Escherichia coli isolates from dogs manifesting attaching and effacing lesions. J Clin Microbiol 34: 144-154.

30. Pradel N, Livrelli V, De Champs C (2000) Prevalence and characterization of shiga toxin- producing Escherichia coli isolated from cattle, food, and children during a one-year prospective study in France. J Clin Microbiol 38: 1023-1031.

31. Monteiro-Neto V, Campos L, Ferreira A, Gomes T, Trabulsi L (1997) Virulence properties of Escherichia coli O111:H12 strains. FEMS Microbiol Lett146: 123-128.

32. Tornieporth N, John J, Salgado K, De Jesus P, Latham E, Melo M, Gunzburg S, Riley L (1995) Differentiation of pathogenic Escherichia coli strains in Brazilian children by PCR. J Clin Microbiol 33: 1371-1374.

33. Vial PA, Mathewson JJ, DuPont HL, Guers L, Levine MM (1990) Comparison of two assay methods for patterns of adherence to HEp-2 cells of Escherichia coli from patients with diarrhoea. J Clinl Microbiol 28: 882-885. 
34. Audu R, Omiliabu S, Renner J, Awodiji J (2000) Risk Factors, Clinical Features and Management of Children With Diarrhea in Lagos. J Niger Assoc Infect Control 3: 24-29.

35. Vilchez S, Reyes D, Paniagua M, Bucardo F, Mollby R, Weintraub A (2009) Prevalence of diarrheagenic Escherichia coli in children from Leon, Nicaragua. J Med Microbiol 58: 630-637.

36. Okeke I, Lamikanra A, Steinrück H, Kaper J (2000) Characterization of Escherichia coli Strains from Cases of Childhood Diarrhea in Provincial Southwestern Nigeria. J Clin Microbiol 38: 7-12.

37. Nguyen RN, Taylor LS, Tauschek M, Robins-Browne RM (2005) Atypical enteropathogenic Escherchia coli infection and prolonged diarrhea in children. Emerg Infect Dis 12: 597603.

38. Ratchtrachenchia O, Subpasu S, Hideo H, Ba-Thein W (2004) Prevalence of childhood diarrhea-associated Escherichia coli in Thailand. J Med Microbiol53: 237-243.

39. Rivera F, Ochoa T, Maves R, Bernal M, Medina A, Meza R, Barletta F, Mercado E, Ecker L, Gil A, Hall E, Huicho L, Lanata C (2010) Genotypic and phenotypic characterization of enterotoxigenic Escherichia coli strains isolated from Peruvian children. J Clin Microbiol 48: 3198-3203.

40. Ozerol I, Bayraktar M, Iseri L, Otlu B, Durmaz R (2005) The prevalence and molecular typing of enterotoxigenic Escherichia coli strains isolated from diarrheic stools in Malatya, Turkey. New Microbiol 28: 237-243.

41. Orlandi P, Magalhaes G, Matos B, Silva T, Penatti M, Nogueira P, Silva L (2006) Etiology of diarrheal infections in children of Porto Velho (Rondonia, western Amazon region, Brazil). Braz J Med Biol Res 39: 507-517

42. Paul M, Tsukamoto T, Ghosh A, Bhattacharya S, Manna B, Chakrabarti S, Nair G, Sack D, Sen D, Takeda Y (1994) The significance of enteroaggregative Escherichia coli in the etiology of hospitalized diarrhea in Calcutta, India and the demonstration of a new honey-combed pattern of aggregative adherence. FEMS Microbiol Lett 117: 319-325.
43. González R, Díaz C, Mariño M, Cloralt R, Pequeneze M, Pérez-Schael I (1997) Age-specific prevalence of Escherichia coli with localized and aggregative adherence in Venezuelan infants with acute diarrhea. J Clin Microbiol 35: 1103-1107.

44. Jalaluddin S, de Mol P, Hemelhof N, Bauma D, Brasseur P, Hennart R, Lomoyo E, Rowe B, Butzler J (1998) Isolation and characterization of enteroaggregative Escherichia coli (EAggEC) by genotypic and phenotypic markers, isolated from diarrheal children in Congo. Clin Microbiol Infect 4: 213-219.

45. Nataro J, Steiner T, Guerrant R (1998) Enteroaggregative Escherichia coli. Emerg Infect Dis 4: 251-261.

46. Brown J, Echeverria P, Taylor D, Seriwatana J, Vanapruks V, Lexomboon U, Neill R, Newland J (1989) Determination by DNA hybridization of Shiga-like-toxin-producing Escherichia coli in children with diarrhea in Thailand. J Clin Microbiol 27: 291-294.

47. Strockbine N, Faruque S, Kay B, Haider K, Alam K, Alam A, Tzipori S, Wachsmuth I (1992) DNA probe analysis of diarrheagenic Escherichia coli: detection of EAF-positive isolates of traditional enteropathogenic E. coli serotypes among Bangladeshi paediatric diarrhea patients. Mol Cell Probes6: 93-99.

48. Ogunsanya T, Rotimi V, Adenuga A (1994) A study of the aetiological agents of childhood diarrhea in Lagos, Nigeria. J Med Microbiol 40: 10-14.

\section{Corresponding author}

Casmir Ifeanyichukwu Cajetan Ifeanyi

Department of Veterinary Microbiology

Faculty of Veterinary Medicine

University of Abuja

P.M.B 117 Abuja, Nigeria

Phone: +2348030750990

Email: ifeanyi.casmir@gmail.com

Conflict of interests: No conflict of interests is declared. 